\title{
Pemberdayaan Siswa Dusun Cimuda Dalam Pembelajaran Matematika Melalui Bimbel Dimasa Pandemi Covid-19
}

\author{
Empowerment of Cimuda Village Students in Learning Mathematics Through Tutoring \\ During the Covid-19 Pandemic \\ Neli Agustin ${ }^{1}$, Yopi Nisa Febianti ${ }^{2}$ \\ 1,2 Porgram Studi Pendidikan Matematika, Fakultas Keguruan dan Ilmu Pendidikan, Universitas Swadaya \\ Gunung Jati Cirebon, Indonesia \\ E-mail : ${ }^{1}$ agustinneli541@gmail.com, ${ }^{2}$ yopinisa@gmail.com
}

\begin{abstract}
Abstrak
Pemberdayaan adalah upaya untuk membangun daya dengan mendorong, memberikan motivasi, dan membangkitkan kesadaran akan potensi yang dimilikinya, serta berupaya untuk mengembangkannya, juga memperkuat potensi yang dimiliki. Penelitian ini dilakukan dengan pemberdayaan siswa dalam memahami materi matematika melalui upaya pengadaan bimbingan belajar di lingkungan masyarakat. Jenis penelitian ini adalah penelitian lapangan yang bersifat analisis deskriptif, Penelitian ini dilakukan di Dusun Cimuda, Desa Mekarjaya, Kecamatan Ciawigebang, Kabupaten Kuningan, Provinsi Jawa Barat, dengan melibatkan siswa kelas 6 SD/MI sebagai subjek penelitian. Kegiatan bimbingan belajar ini, meliputi pemberian materi matematika yang sedang dipelajari di sekolah, pemberian latihan materi dengan intensitas yang lebih tinggi, pemberian materi matematika yang belum dipelajari di sekolah, pelatihan ingatan terkait perkalian bilangan, bimbingan mengerjakan tugas sekolah, serta pemberian tugas dan pekerjaan rumah pada kegiatan bimbingan belajar. Dengan menggunakan teknik pembelajaran tersebut, peneliti melakukan pemberdayaan siswa di Dusun Cimuda. Kata kunci-Pemberdayaan Siswa, Pandemi Covid-19, Bimbingan Belajar Matematika.
\end{abstract}

\begin{abstract}
Empowerment is an effort to build power by encouraging, motivating, and raising awareness of its potential, as well as trying to develop it, as well as strengthening its potential. This research was conducted by empowering students in understanding mathematics material through efforts to provide tutoring in the community. This type of research is field research which is descriptive analysis. This research was conducted in Cimuda Hamlet, Mekarjaya Village, Ciawigebang District, Kuningan Regency, West Java Province, involving students of grade 6 SD / MI as research subjects. This tutoring activity includes providing mathematics material that is being studied at school, providing training with material with a higher intensity, providing mathematics material that has not been studied in school, memory training related to multiplication of numbers, guidance on doing school work, and giving assignments and homework. on tutoring activities. By using these learning techniques, researchers empowered students in Cimuda Hamlet.
\end{abstract}

Keyword - Empowerment of Students, The Covid-19 Pandemic, Math Tutoring.

\section{PENDAHULUAN}

Revolusi adalah sebuah perubahan besar yang berlangsung secara cepat menyangkut dasar-dasar atau pokok kehidupan masyarakat (Ariah dkk., 2020). Revolusi industri 4.0 merupakan perubahan kemajuan teknologi yang menerapkan dunia digital, dimana terdapat perubahan cara hidup yang serba cepat dan berdampak pada kehidupan manusia (Slusarczyk, 2018). Era revolusi industri 4.0 ini ditandai dengan berkembangnya internet of things yang merabah di berbagai elemen kehidupan masyarakat, salah satunya dalam bidang pendidikan. Seiring dengan berkembangnya teknologi, cara belajar mengajar di era revolusi industri 4.0 juga mengalami perubahan, terutama di masa kini dengan merebaknya pandemi covid-19. Wabah global yang melanda dunia mengakibatkan segala sesuatu termasuk proses belajar mengajar dilakukan secara online, sebagai upaya menekan perluasan covid-19. Dampak yang dirasakan

Submitted: Juli 2021, Accepted: Agustus 2021, Published: Agustus 2021

ISSN 2746-6345 (media online) 
dari pembelajaran jarak jauh tentu salah satunya menjadikan proses belajar mengajar tidak seoptimal pembelajaran di dalam kelas. Hal ini sangat terasa di beberapa cakupan materi pelajaran yang terbilang abstrak yang dalam proses memahaminya siswa membutuhkan penjelasan guru secara langsung. Salah satu contohnya adalah mata pelajaran matematika. Sebagaimana penelitian Mustakim (2020) menyebutkan bahwa, salah satu kendala terberat dalam pembelajaran daring adalah mengajar mata pelajaran matematika.

Kendala inilah yang mendorong peneliti untuk melakukan upaya pemberdayaan terhadap siswa dalam memahami materi matematika. Pemberdayaan merupakan suatu upaya yang dilakukan guna memperbaiki kualitas hidup sumber daya manusia (SDM) dengan cara membuat mereka berdaya, memiliki semangat bekerja untuk memerangi kekurangan dan keterbelakangan masyarakat dengan harapan membangun diri mereka sendiri untuk lebih maju dan sejahtera (Retno dkk., 2015). Pemberdayaan siswa dalam membantu memahami materi matematika ini dilakukan melalui upaya pengadaan bimbingan belajar di lingkungan masyarakat. Bimbingan belajar adalah jenis bimbingan yang memberikan bantuan kepada individu dalam memecahkan kesulitan-kesulitan yang berhubungan dengan masalah belajar (John Gottman, 2001). Bimbingan belajar juga akan menunjang keberhasilan pendidikan anak. Seperti yang diungkapkan Ahmad (2015) bahwa, seorang anak selain mendapat pendidikan formal juga harus mendapatkan pendidikan informal yang diperolehnya di lingkungan masyarakat dan keluarga. Upaya ini diharapkan dapat membantu anak/siswa agar lebih mengerti pelajaran matematika di sekolah secara lebih mendalam.

Penelitian ini memunculkan rumusan masalah, yakni bagaimana cara untuk memberdayakan siswa dalam memahami materi matematika di masa pandemi covid-19? Berdasarkan hal tersebut, perlu adanya upaya yang dapat membantu dalam memecahkan permasalahan yang ada. Terlebih dengan adanya wabah covid-19 yang berdampak pada kurang optimalnya pembelajaran matematika. Maka dari itu, dalam penelitian ini peneliti memiliki ide untuk memberdayakan siswa sekolah kelas VI SD (upaya membantu siswa menghadapi ujian tingkatan sekolah) di lingkungan Dusun Cimuda, Desa Mekarjaya, Kecamatan Ciawigebang, Kabupaten Kuningan (tempat peneliti melaksanakan kegiatan Kuliah Kerja Nyata) melalui bimbingan belajar matematika.

\section{METODE PELAKSANAAN}

Jenis penelitian ini adalah penelitian lapangan (survei lapangan), yang bersifat analisis deskriptif, yaitu mengumpulkan dan menyusun data kemudian menganalisis dan menginterpretasikan data tersebut. Penelitian ini dilakukan dalam pelaksanaan kegiatan pengabdian masyarakat dalam Kuliah Kerja Nyata yang peneliti lakukan di Desa Mekarjaya, Kecamatan Ciawigebang, Kabupaten Kuningan, Provinsi Jawa Barat, dengan melibatkan siswa kelas 6 SD/MI di lingkup Dusun Cimuda, Desa Mekarjaya, sebagai subjek penelitian. Tempat kegiatan pengabdian bimbingan belajar ini dilaksanakan di salah satu tempat mengaji anak, yakni di Madrasah Nurul Ilmi. Pelaksanaan kegiatan ini dilakukan dari tanggal 9 Februari hingga 16 Maret 2021 dengan 3 kali tatap muka dalam satu minggu. Metode yang digunakan dalam proses pengumpulan data ini melalui teknik observasi langsung serta wawancara. Jenis data dalam penelitian ini tergolong data kualitatif dengan teknik analisis data secara naratif deskriptif.

\section{HASIL DAN PEMBAHASAN}

Berdasarkan hasil observasi yang peneliti lakukan di Dusun Cimuda, Desa Mekarjaya, Kecamatan Ciawigebang, Kabupaten Kuningan, diperoleh gambaran terkait pembelajaran sekolah yang salah satu tema pelajarannya terbilang cukup sulit dilakukan secara optimal melalui pembelajaran daring. Pembelajaran ini yakni pembelajaran matematika. Kendala dalam proses pembelajaran ini mendorong peneliti untuk melakukan upaya pemberdayaan terhadap 
siswa dalam mempelajari matematika di lingkup Dusun Cimuda (tempat peneliti tinggal dan melaksanakan kegiatan KKN). Menurut Kamus Besar Bahasa Indonesia (2014), pemberdayaan adalah proses, cara, dan perbuatan memberdayakan. Pemberdayaan dapat pula dilihat dari sisi keberadaannya sebagai suatu program atau sebagai suatu proses (Adi, 2013). Pemberdayaan sebagai suatu program, dilihat dari tahapan-tahapan kegiatan guna mencapai suatu tujuan yang biasanya sudah ditentukan jangka waktunya. Oleh karena itu, pemberdayaan adalah upaya untuk membantu seseorang atau kelompok dengan menolong diri mereka melalui pengembangan kemampuan yang nantinya dapat diberdayakan dalam meningkatkan taraf hidupnya.

Pemberdayaan siswa yang dilakukan disini, yakni melalui kegiatan bimbingan belajar serta difokuskan pada kebutuhan pendidikan masyarakat. Hal ini didukung oleh faktor yang salah satunya sebagai sarana dalam membantu pemahaman siswa pada materi pelajaran matematika yang umumnya membutuhkan sentuhan langsung, serta berbagai macam pengulasan materi dalam memperkuat dasar serta konsep matematis setiap siswa. Berikut Gambar 1 adalah gambaran kegiatan bimbingan belajar yang dilakukan.

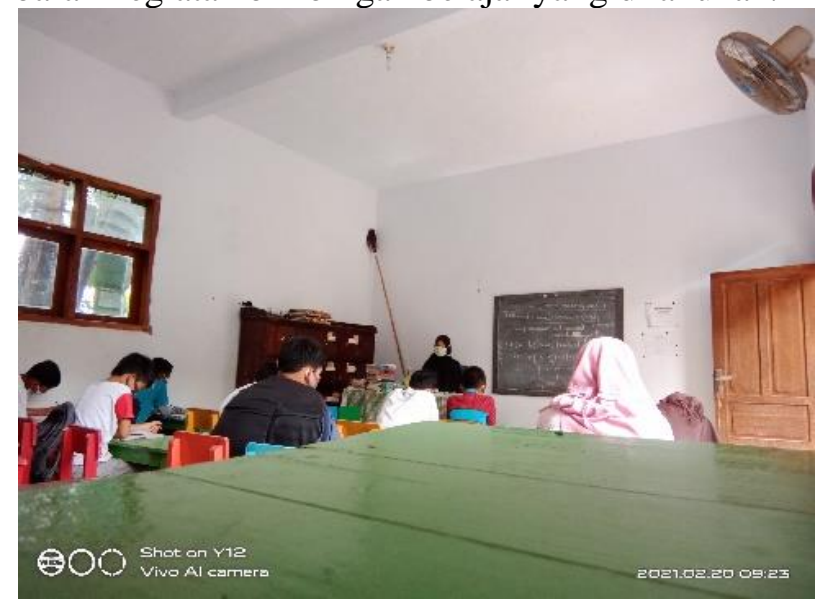

Gambar 1. Kegiatan bimbingan belajar di Dusun Cimuda, Desa Mekarjaya

Kegiatan bimbingan belajar ini, meliputi pemberian materi matematika yang sedang dipelajari di sekolah, pemberian latihan materi dengan intensitas yang lebih tinggi, pemberian materi matematika yang belum dipelajari di sekolah, pelatihan ingatan terkait perkalian bilangan, bimbingan mengerjakan tugas sekolah, serta pemberian tugas dan pekerjaan rumah pada bimbingan belajar.

Kegiatan bimbingan belajar dilakukan tiga kali selama satu minggu, yaitu setiap hari Jumat, Sabtu, dan Minggu selama masa KKN. Dengan jadwal kegiatan pada Tabel 1 sebagai berikut.

Tabel 1. Jadwal Kegiatan Bimbingan Belajar

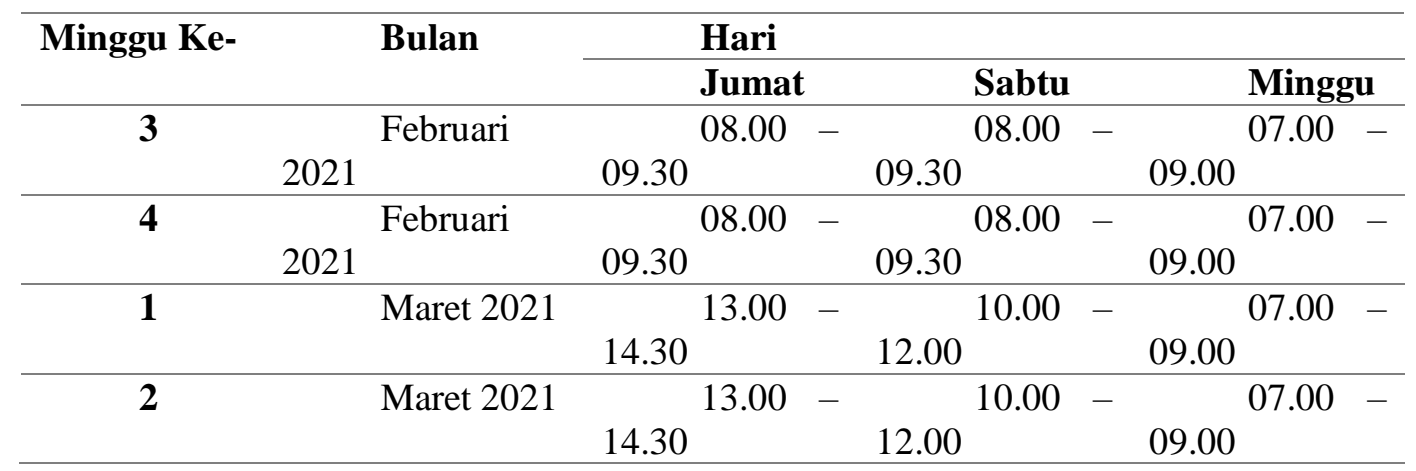

Bimbingan belajar adalah proses pemberian bantuan atau pertolongan kepada siswa dalam menentukan pilihan, penyesuaian serta pemecahan masalah belajar yang berkaitan 
dengan perubahan tingkah laku sebagai akibat dari pengalaman, latihan maupun rangsangan (Rosaria dkk., 2017). Bimbingan belajar merupakan upaya untuk membantu siswa dalam mengatasi masalah belajarnya dan untuk bisa belajar dengan lebih efektif. Sedangkan, masalah belajar adalah suatu kondisi tertentu yang dialami seorang murid dan menghambat kelancaran proses belajarnya. Dalam kegiatan bimbingan belajar ini, tentu akan ada banyak hal yang bisa dimaknai. Proses kegiatan bimbingan belajar ini, meliputi hal-hal sebagai berikut.

1. Kegiatan belajar dengan membantu siswa memahami materi matematika yang sedang dipelajari di sekolah.

Kegiatan bimbingan belajar ini sangat membantu siswa sekolah untuk lebih memahami materi matematika yang kurang dikuasai oleh siswa selama di sekolah. Kegiatan pembelajaran matematika di masa belajar daring menuntut siswa belajar tanpa adanya bimbingan secara langsung dari guru. Dengan adanya kegiatan bimbingan belajar, siswa menjadi terbantu dalam segi pemahaman materi yang sedang dipelajari, serta sangat berdampak pada keseharian siswa di sekolah karena siswa menjadi lebih aktif dalam kegiatan belajar matematika. Dari kegiatan ini, anak diajarkan dan diberi penjelasan lebih khusus dan mendalam. Dan melalui bimbingan belajar pula, anak akan lebih fokus belajar dan mengerti pelajaran, tidak hanya mengandalkan materi yang diberikan dari sekolah saja.

2. Kegiatan belajar dengan membantu siswa mengerjakan tugas-tugas matematika yang diberikan di sekolah.

Dalam kegiatan bimbingan belajar ini, siswa diberikan ruang untuk melakukan konsultasi terkait tugas sekolah, serta siswa akan dibimbing secara tuntas dalam mengerjakan tugas-tugas matematika sekolah.

3. Membantu siswa untuk lebih cerdas dalam belajar matematika.

Proses bimbingan belajar ini menuntut siswa lebih cerdas dalam belajar matematika, salah satunya dengan proses pembelajaran yang sangat menarik dan rileks, serta siswa diberikan drill/ latihan soal dengan intensitas yang lebih tinggi.

4. Membantu siswa untuk mendapatkan pengalaman belajar.

Pembelajaran ini memungkinkan siswa mendapatkan materi dan pengalaman belajar yang lebih dibandingkan siswa yang tidak mengikuti kegiatan bimbingan belajar. Siswa dibimbing di luar jam pelajaran secara intensif oleh peneliti dalam memahami materi matematika secara mendalam dan lebih luas.

5. Menanamkan pemahaman terhadap siswa terkait pentingnya mencuci tangan di masa pandemi covid-19.

Selain sosialisasi, penanaman pemahaman terkait pentingnya mencuci tangan juga diterapkan dengan mempraktekkan secara langsung di kehidupan sehari-hari. Hal ini didukung dengan siswa selalu mencuci tangan sebelum melakukan kegiatan bimbingan belajar. Gambar 2 menunjukkan hal tersebut.

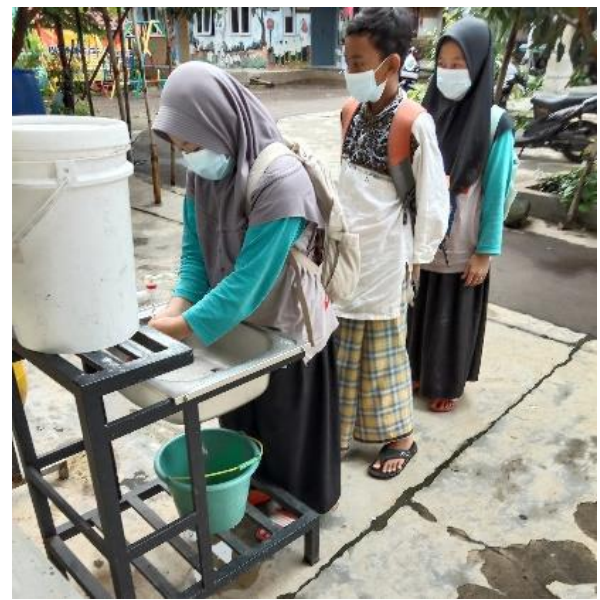

Gambar 2. Gerakan Mencuci Tangan Sebelum Belajar 
6. Sarana dalam upaya membantu siswa menghadapi ujian kenaikan tingkatan.

Peraturan pemerintah yang menekankan tidak adanya ujian nasional di setiap jenjang pendidikan tidak menutup kemungkinan seorang siswa tidak menghadapi ujian. Hal ini dikarenakan bahwa, walaupun ujian nasional tidak ada tetapi ujian sekolah dilaksanakan. Hal itulah yang mendorong para siswa untuk tetap mempersiapkan diri dalam menghadapi ujian kenaikan tingkatan, khususnya siswa SD yang akan naik ke tingkat SMP. Dengan bimbingan belajar matematika, siswa disiapkan dalam menghadapi ujian dan melaksanakan belajar dengan tekun.

Meningkatnya antusiasme siswa dalam mengikuti kegiatan bimbingan belajar.

Kegiatan bimbingan belajar ini juga terdapat faktor pendukung yang menambah semangat belajar, antara lain yaitu antusiasme siswa dalam pelaksanaan kegiatan, dan adanya kesadaran dari anak-anak akan pentingnya menuntut ilmu pengetahuan. Hal ini ditandai dengan meningkatnya semangat siswa dalam mengikuti kegiatan bimbingan belajar, dibuktikan dengan sebagian besar siswa datang lebih awal sebelum kegiatan bimbingan belajar dimulai. Dalam pelaksanaan kegiatan pun, siswa aktif bertanya serta saling mendahului dalam mengumpulkan latihan demi latihan.

\section{KESIMPULAN}

Berdasarkan hasil penelitian yang telah dilakukan dapat disimpulkan bahwa, kegiatan bimbingan belajar di masa pandemi covid-19 ini memberikan dampak positif serta dapat meningkatkan semangat belajar dari dalam diri siswa. Hal ini dibuktikan dengan kemampuan siswa yang terus meningkat selama kegiatan bimbingan belajar. Kegiatan bimbingan belajar ini dilakukan sebagai upaya pemberdayaan siswa dalam belajar matematika di masa pembelajaran daring. Dari hasil observasi juga menunjukan keberhasilan pemberdayaan siswa dalam belajar matematika di masa pandemi covid-19.

\section{DAFTAR PUSTAKA}

(2014). Kamus Besar Bahasa Indonesia Pusat Bahasa. Jakarta: PT Gramedia Pustaka Utama.

Adi, Isbandi Rukminto. (2013). Intervensi Komunitas: Pengembangan Masyarakat Sebagai Upaya Pemberdayaan Masyarakat. Jakarta: Rajawali Pers.

Ahmad, Komaruzaman. (2015). Pengaruh Persepsi Siswa Tentang MetodeMangajar Guru, Fasilitas Belajar dan Motivasi Belajar Terhadap Prestasi Belajar Siswa Kompetensi Keahlian Teknik Audio Video di SMK N3 Yogyakarta. Tesis, UNY.

Ariah, dkk. (2020). Pemberdayaan Rumah Literasi Dalam Meningkatkan Semangat Belajar Siswa Di Era Revolusi Industri 4.0. Educivilia, 1(2), 169-175.

John Gottman. (2001). Kiat-Kiat Membesarkan Anak yang Memiliki Kecerdasan Emosional. Jakarta: Gramedia Pustaka Utama.

Mustakim. (2020). Efektivitas Pembelajaran Daring Menggunakan Media Online Selama Pandemi Covid-19 pada Mata Pelajaran Matematika. Journal of Islamic Education, 2(1), $1-12$.

Retno, S. S., Rohmiyati, Y., \& Husna, J. (2015). Pemberdayaan Masyarakat Melalui Perpustakaan: Studi Kasus di Rumah Pintar "Sasana Ngudi Kawruh" Kelurahan Bandarharjo-Semarang. Jurnal Ilmu Perpustakaan, 4(2), 1-10.

Rosaria, D., Novika, H. (2017). Bimbingan Belajar Bahasa Inggris Bagi Anak Usia Sekolah Dasar (6-12 Tahun) Di Desa Semangat Dalam Rt.31 handil Bhakti. Jurnal Al-Ikhlas, 2 (2).

Sabirin, Muhamad. (2014). Refresentasi dalam Pembelajaran Matematika. JPM IAIN Antasari, $1(2), 33-44$. 
Slusarczyk, B. (2018). Industry 4.0 - Are we ready? Polish Journal Of Management Studies, 11(5), 77-90. 